forthcoming monograph, Eusebius of Caesarea: Textuality and Tradition in Late Ancient Christianity.

For reasons I'll make clear below, I think it is easily the best single volume edition of the Ecclesiastical History now available in English. As I do not have substantive criticisms of the present volume, I'll endeavour to show why it will, I think, become the definitive translation and edition of the Ecclesiastical History for scholarly and classroom purposes. (Others have spoken to its achievement qua translation; here I note its impact for the general reading public.)

I'll start with a bit of background on Eusebius' History, say more about Schott's achievements in this edition, and conclude with some notes on its classroom effectiveness.

Eusebius' Ecclesiastical History (traditionally Historia Ecclesiastica) is our principal historical source detailing the early years of the Christian Church in the eastern Mediterranean. (One of the criticisms of Eusebius is his relative ignorance of Christianity's emerging Latin dimension in the Roman West.)

In it, Eusebius charts the parallel history of the successive regimes of Roman emperors and their provincial governors in the Roman East and the accession of the ecclesiastical government of the Eastern Church. The Church begins with Jesus, spreads under the proselytising of the Apostles and the sacrifices and persecution of the martyrs under Rome, and eventually organises around ancient urban episcopacies in the Greek-speaking East and in Rome itself.

The Roman empire, in contrast, undergoes successive convulsions of insurrection and invasion, resulting in infighting that threatens to tear the empire in two.

In a climactic conclusion to his history, Eusebius combines the narrative of these two parallel polities in Constantine's military and political triumph, on the one hand, and his conversion to Christianity (in hoc signo vinces), on the other, completing a synthesis of Rome and the Christian Church.

The Ecclesiastical History, then, presents a rich, unparalleled source for Early Church and Roman imperial history and a vivid contemporary account of how late ancient Romans made sense of the Constantinian ascendancy.

But its importance has not necessarily translated into sustained scholarly engagement or, even, much student interest. For while it has been a busy season for Eusebian studies since the publication of T.M. Barnes' Constantine and Eusebius (Harvard UP 1981), most commentators have focused on other parts of Eusebius' many-faced oeuvre, elaborating on Eusebius as apologist and dogmatist. This might be due to the uneven, complicated structure for the Ecclesiastical History and its heavy use of quotation from other (often lost) sources. This makes the text confusing for the general reader and scholar alike.

And so Schott's contribution in the form of a readable, well-introduced translation with extensive, helpful notes is a seminal event in scholarship of the Early Church.

In addition to the translation and notes, Schott has included a spectacular 30-page introduction pitched for the general reader, an introductory overview that includes parallel ancient Christian and 'pagan' sources for the dates covered in Eusebius' chronology, extensive notes, two helpful appendices, and an excellent bibliography.

Together, these make for a singular achievement in Eusebian studies. I anticipate this volume will become the standard translation, and generations of students and teachers will appreciate Eusebius through this edition.

\section{Seneca: Medea}

Slaney, H. Pp. vi + 198, ills. London and New York: Bloomsbury Academic, 2019. Cased, $£ 70$.

ISBN: 978-1-4742-5661-6.

\section{Edmund Gazeley \\ Merchant Taylors' School, Northwood}

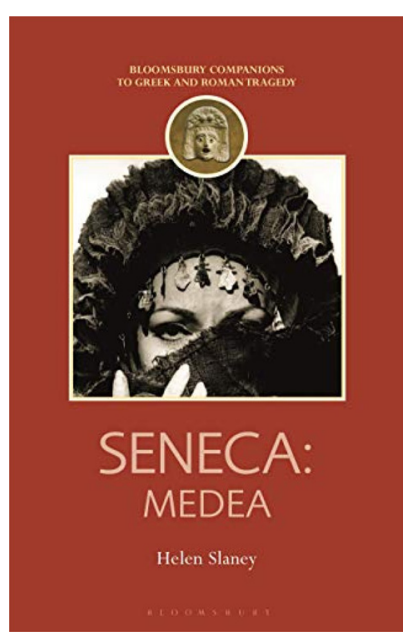

This book, as part of the 'Bloomsbury Companions to Greek and Roman Tragedy', offers an extensive, thoroughly researched, and sometimes unexpected range of perspectives on Seneca's Medea. The structure of the work is taut, with the first four chapters covering the usual topics for an introductory volume, viz the play in its historic and generic context, the plot in its mythological context, key themes, and features of style.

Alongside the traditional historical readings of Seneca's tragedy, such as comparisons with contemporary imperial figures, Slaney draws on the entire Senecan corpus to inform readings of the play in its own time; there is a focus on his Stoic essays, and a particularly striking section against the traditional reading of Medea's anger and actions as a negative exemplum (pp.7-8). Slaney is happy to present contradictory readings without dictating conclusions; this is one of the book's strongest features.

The second chapter, exploring the inheritance, Senecan innovations, and later reception of the Medea myth is similarly expansive, covering familiar intertextual references to Euripides, Ovid, and Apollonius Rhodius. Among these, the identification of Seneca's Medea as a mid-point in a specifically Roman tradition, for instance the significance of the Argo as prima ratis (pp.43-45), is compelling and a neat illustration of the concept of intertext. The real highlight of the chapter is the inclusion of a detailed exploration of Greek and Roman artistic representations of the Medea myth, given equality with literary readings.

Three key themes are selected for particular exploration: repetition and return; the natural world; metatheatre. Of these Slaney is best on the natural world, as she draws together and compares examples from across the play. The section on metatheatre was ripe for development into a discussion on Roman theatre more generally, and was perhaps a missed opportunity, but nonetheless could provide a good starting point for further investigation. In the fourth chapter, Slaney passionately argues against perceptions of Seneca's Latin as bombastic. She makes emphatic use of word frequency analysis, with focus both on the impact of repeated use, and the totemic power of a single word.

However, it is in the final section of the fourth chapter, as well as the two following, that this work departs from what is typically expected of a general introduction. Slaney has a background in Reception Studies, and employs detailed explorations of non-classical translations and stagings to illuminate her reading of Seneca. For instance, the section on the first English translation (Studley, 1566) is 11 pages long (pp.108-118), and follows a narrative on how Studley's verbosity 
changed perceptions of Seneca's Latin. Similarly, a promising chapter on 'Witchcraft and Stagecraft' (pp.119-139) is initially informative on Roman attitudes regarding witchcraft, but then follows a long diversion on French theatre and specifically Corneille's 1635 staging of Medée. This is successful as a close reading between Seneca and Corneille, but incongruous as a chapter within a general introduction, and not necessarily of interest to the Classicist, who may have preferred a chapter on comparisons between Seneca and Euripides.

The final chapter seeks to define Seneca's version of the myth within the web of intertext, and among the multiple modern re-readings and re-stagings. Here the lighter touch, covering a greater number of examples and across more artistic genres, but in less detail, is welcome, and encourages an appreciation for the uniquely Senecan elements of the Medea myth. This style is more within the remit of a general introduction.

This book is eminently suitable for the undergraduate reading Seneca or exploring Reception, and I would suggest that the first four chapters would be useful for a student in secondary education. Parts of the book would even benefit those reading Euripides' version of the myth, or Seneca's letters, as his philosophy is often linked to his creative output. The extensive notes and bibliography also provide many opportunities for further exploration to interested readers.

doi:10.1017/S2058631020000306

\section{The Story of Greece and Rome}

Spawforth (T.) Pp. $x+375$, maps, b/w \& colour pls. New Haven, CT and London: Yale University Press, 2018. Cased, £20, US\$30. ISBN: 978-0-300-21711-7.

\section{Barry Knowlton}

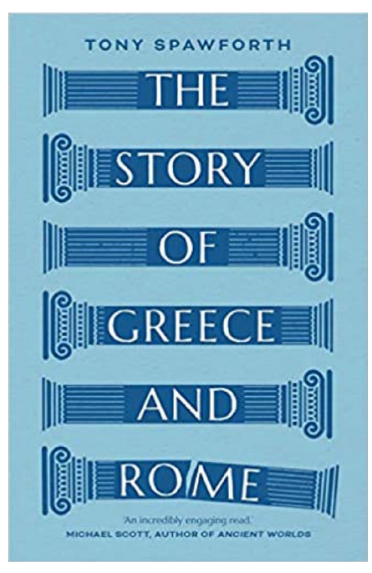

The story of Greece and Rome is a familiar one; unless it isn't anymore. If it isn't, then it needs to be retold; and Tony Spawforth would seem to be a good man for the job. He is an emeritus professor of Ancient History, the author of several books, and the presenter of many documentaries. I watched one of these; in which a young Tony Spawforth enthusiastically pursues the mortal remains and immortal glory of Alexander the Great. He says that he'd loved such things as a boy, and so had become an archaeologist. He journeys to out-of-the-way excavations and returns to university museums. He consults with expert colleagues but tells his own story. His story of Greece and Rome might have been the basis of another documentary or two; but that it is a book makes it of more educational interest.

If the story of Greece and Rome is no longer as familiar as it was, it is because fewer people read about it. Documentary films are supposed to take the place, or supply the lack, of a more literate engagement with the history of antiquity. Ideally, a documentary illustrates and supplements the viewers' reading. But if there were no more books on Greece and Rome, there would soon be no more films; just as if there were no museums, there would be no archaeological findings, only out-of-the-way ruins.

Spawforth says that his story is aimed at readers who are interested enough in the topic to start reading this book, but who have little or no background in the disciplines of Classics or Ancient History' (11). As I read, it seemed to me that the book might find an audience either among young students in an introductory survey, or among older world travellers. Spawforth is determined to make it 'relatable', with plenty of references to the present day and its popular culture. But most of the time he spends in the present day he spends in the museums that house the artifacts of classical antiquity. He seems to have been to every one in the world, and to know not only the Greek and Roman holdings but the histories of their acquisitions. As I read I was often reminded of Herodotus, who would often adduce in support of his inquiries what he himself saw in the places he had personally visited.

Spawforth also calls upon the pertinent ancient authors, but presents them in an unconventional way. He indeed does not assume that his audience has them in their background. Thus in describing the Minoan civilisation he quotes a passage about the power of King Minos; and only afterward identifies Thucydides as its author. An observation about Roman power is attributed to 'a Greek writer called Polybius' (94). Spawforth tells us of 'an Athenian philosopher writing in the early to mid-300s BC', before he tells us that it is Plato (124); and quotes another 'ancient writer' without ever telling us that it is Plutarch. Likewise, he does not assume that his audience knows Pope's Homer, but does take the time to acquaint them with that classic example of classical translation, and then makes a point of quoting Pope when he has occasion to lay out some lines from the Iliad or Odyssey. And in his extensive use of Herodotus we can see what can come of a pedagogical rather than a scholarly exposition of an unfamiliar but important ancient author.

The Story of Greece and Rome sorts out the Greeks and Romans so as to keep them clear and distinct, but not so as to elide their interactions. The individual chapters are well organised, and the transitions between them should help maintain the interest of students. If it would also appeal to older readers, all the better; and if it comes at Plato or Plutarch in such a way as to distract any conventionally textual teachers, let it be a salutary reminder of the circumstances in which we now would teach our students about Greece and Rome.

doi:10.1017/S2058631020000318

\section{Beyond the Nile. Egypt and the Classical World}
Spier, J., Potts, T., and Cole, S. (Eds). Los Angeles, Getty Museums. ISBN 978-1606065518. Pp. 360. Ill. 200. Hardback. $£ 45.00$.

\section{Steven Hunt \\ University of Cambridge}

This is the catalogue of the eponymous exhibition presented at the J. Paul Getty Museum in Los Angeles in 2018. It is a weighty volume, 